Sains Malaysiana 49(6)(2020): 1381-1388

http://dx.doi.org/10.17576/jsm-2020-4906-16

\title{
The Use of Fall Risk-Increasing Drugs among Older People in Nursing Homes
}

(Penggunaan Ubatan yang Meningkatkan Risiko Jatuh dalam Kalangan Warga Tua di Rumah Penjagaan)

\author{
LeE Shiow Ling, MARHANis OMAR*, AdLIAH MHD-Ali \& MOHD MAKMOR-BAKRY
}

\begin{abstract}
Medication use is one of the modifiable risk factors that causes falls. Falls are the leading cause of injury among elderly people. The incidence of falls does significantly impact elderly people's independence in carrying out their regular activities. This study aimed to determine the prevalence of drugs that cause falls and the fall risk status among elderly people residing in nursing homes. A cross-sectional study was conducted on residents in 27 long term care facilities in Malaysia from March 2018 until November 2018 using a researcher-assisted questionnaire. A total of 212 residents were recruited in this study. A majority of the residents were taking at least one fall-risk increasing drug (FRIDs) or orthostatic drug (ODs) $(n=145,68.4 \%)$, with two-thirds of them presenting high risk of falling $(n=95$, $65.5 \%)$. A significant association was found between the use of beta-blocking agents ( $p=0.033)$, renin-angiotensin system inhibitors $(p=0.038)$, length of stay in facilities $(p=0.031)$, frailty status $(p<0.001)$, number of drugs in total $(p=0.010)$ and as needed $(p=0.025)$ with an increased risk of falls. Therefore, a majority of the elderly people residing in nursing homes were proven to be prone to the use of fall-risk medications. Frail elderly people have a higher risk of falling compared to those who were non-frail.
\end{abstract}

Keywords: Drug use; polypharmacy; side-effect

\section{ABSTRAK}

Penggunaan ubat merupakan salah satu faktor risiko yang terubahsuai yang menyebabkan jatuh. Jatuh adalah penyebab utama kecederaan dalam kalangan warga tua. Ini akan memberi kesan kepada warga tua dalam menjalankan aktiviti lazim mereka. Kajian ini bertujuan untuk menentukan ubat-ubatan yang memberi risiko yang menyebabkan jatuh dalam kalangan warga tua yang berada di rumah penjagaan. Satu kajian rentas telah dijalankan dalam kalangan penghuni di 27 rumah penjagaan di Malaysia bermula dari bulan Mac 2018 hingga November 2018 menggunakan borang soal selidik. Seramai 212 penghuni terlibat dalam kajian ini. Majoriti penghuni didapati mengambil sekurangkurangnya satu ubat yang mempunyai risiko untuk jatuh (FRID) atau ubat ortostatik (OD) ( $n=145,68.4 \%)$, dengan dua pertiga daripada mereka mempunyai risiko jatuh yang tinggi $(n=95,65.5 \%)$. Satu kaitan yang penting antara penggunaan agen penghalang beta $(p=0.033)$, perencat sistem renin-angiotensin $(p=0.038)$, tempoh berada di rumah penjagaan $(p=0.031)$, status kelemahan $(p<0.001)$, jumlah ubatan yang diambil secara keseluruhan $(p=$ $0.010)$ dan jumlah ubatan yang diambil bila perlu $(p=0.025)$ dengan peningkatan risiko untukjatuh. Oleh itu, majoriti warga tua yang tinggal di rumah penjagaan terdedah kepada penggunaan ubat yang mempunyai risiko untuk jatuh. Warga tua yang mempunyai sindrom lemah juga mempunyai risiko yang lebih besar untuk jatuh berbanding mereka yang tidak lemah.

Kata kunci: Kesan sampingan; penggunaan ubat; polifarmasi

\section{INTRODUCTION}

Falls are predominantly prevalent among elderly people residing in long-term care facilities in Malaysia; it was reported to account for approximately $30 \%$ of all fall incidences (Ghazi et al. 2017). Falls are the principal cause of injury and hospitalisation among elderly people aged 65 years or above, with residents of long-term care facilities accounting for up to $50 \%$ of patients experiencing recurrent falls (Ryan-Atwood et al. 2017). Fall-risk medication has been a well-known modifiable risk factor in causing falls (van der Velde et al. 2007). Frail elderly people with higher frailty index are subjected to twice the likelihood of receiving potentially inappropriate prescribed medicine. They are also more prone to the adverse effects of drugs due to their reduced resilience and changes in pharmacokinetics and pharmacodynamics profile (Cullinan et al. 2016).

To date, it remains a clinical challenge in determining which medications are the contributors to falls even though with the high current number of studies assessing the association between specific medication classes and the likelihood of experiencing one or more falls. 
Regardless of the different data and empirical methods, many studies have concluded that extra caution must be exercised when prescribing medicine to elderly people since specific drugs or drug classes may increase the risk of injuries (Gribbin et al. 2011). Thereby, this study aimed to determine the prevalence of drugs causing falls and the fall risk status among elderly people residing in nursing homes.

\section{MATERIALS AND METHODS}

A cross-sectional study was conducted on residents of 27 long term care facilities including nursing homes, residential care homes and elderly care centres in Malaysia from March 2018 until November 2018. The targeted population of this study was elderly people living in a nursing home, and a researcher-assisted questionnaire was administered upon their written informed consent. Residents were recruited in this study based on the following criteria: Elderly people aged 65 years and above, staying at a long-term care facility for at least three months and are not bed-ridden. Those who failed to provide informed consent and did not complete the questionnaire were excluded from the study. This study was approved by the Universiti Kebangsaan Malaysia Research Ethics Committee (UKM PPI/111/8/ JEP-2018-306). The FRAIL questionnaire (Morley et al. 2012) was utilised to identify the frailty status among the selected elderly people in the nursing home. The questionnaire was interpreted based on a Frail scale score which ranges from 0-5. The maximum score was 5 , and the minimum score was 0 . The total frailty score was categorised into three levels of frail status which are robust (0), pre-frail (1-2) and frail (3-5). The prevalence of drugs causing falls among elderly people in nursing homes was determined using an established and validated list developed by Milos et al. (2014). Each medication was assigned with a unique WHO Anatomic Therapeutic Chemical (ATC) classification codes regardless of the dosage or number of drugs taken for the individual resident. The assigned ATC codes were further categorised into a specific group of FRIDs or ODs. Data on the FRIDs and ODs were recorded and analysed separately due to the overlapping of certain ATC groups in both FRIDs and ODs, for instance, antipsychotics.

Meanwhile, the participants' fall risk status was assessed using a questionnaire comprised of 12 items with 'yes' and 'no' answers (Rubenstein et al. 2011). The fall risk questionnaire (FRQ) score was obtained by summing the total number of points for all 'yes' responses. A risk cut-off point was determined as a minimum of 4 points and above. Residents who scored 4 and above were categorised as high risk of falling, and vice versa. All data analysis was performed using Statistical Package for Social Science (IBM Corp. Released 2012. IBM SPSS Statistics for Windows, Version 21.0. Armonk, NY: IBM Corp.). Data on demographic characteristics, frailty status, presence of at least one
FRID or OD, prevalence of FRIDs and ODs, and items of fall risk questionnaire were analysed using descriptive analysis. Normality assumptions were checked using the Shapiro-Wilk test for the dependent variables and tests used were deemed as appropriate. Chi-square analysis was performed to determine the association between fall risk status and demographic characteristics, frailty status, and the presence of at least one FRID or OD. The Mann-Whitney U Test was used to determine the differences in the distribution of drug types among total number of drugs, FRIDs and ODs in accordance with fall risk status. Similarly, the group comparison of fall risk status with the corresponding classification of FRIDs and ODs was assessed using the Mann-Whitney $\mathrm{U}$ Test. Univariate and multivariate logistic regression were performed to identify the predictive factors for high fall risk among elderly people living in nursing homes. The significance of each predictor variable was tested as a univariate predictor of the total number of risk factors. Factors that had a p-value of $<0.05$ at univariate analysis were included in the multivariate logistic regression. The strength of the association was summarised as an odds ratio with a $95 \%$ confidence interval. Risk factors with a statistically significant $\mathrm{p}$-value of $<0.05$ in the multivariate analysis were selected for inclusion into the prediction model.

\section{RESULTS AND DISCUSSION}

The baseline characteristics of 212 residents from the groups of high risk falling and low risk falling are presented in Table 1. The age group distributions of both resident groups were almost similar, with 70-74 years $(n=49,23.1 \%)$ and $75-79$ years $(n=47 \%, 22.2 \%)$ accounting for the most percentage of residents. More than half of the residents were classified as pre-frail $(n=122,57.5 \%)$. A total of $145(68.4 \%)$ residents were taking at least one FRID or OD, with $95(65.5 \%)$ of them presenting a high risk of falling. Overall, the length of stay in facilities $(p=0.031)$, frailty status $(p<0.001)$ and the number of drugs taken in total $(p=0.010)$ and as needed $(p=0.025)$ were significantly associated with an increased risk of falls. In particular, the pre-frail $(n=104$, $85.2 \%)$ and frail $(n=13,92.9 \%)$ status mainly predispose residents to a higher risk of falling. Residents who had an elevated risk of falls were more likely to take a greater amount of total ODs (mean rank=108.65), both continuously (mean rank $=108.26$ ) and as needed (mean rank $=107.05)$. Conversely, only FRIDs prescribed as needed (mean rank $=107.64)$ were higher in the high-risk group. The total number of FRIDs (mean rank=105.55) and those in continuous use (mean rank=104.47) were observed to be lower in the high-risk group.

Table 2 summarises the prevalence of ATC groups for FRIDs and ODs between the independent high risk of falling and low risk of falling groups. N05A $(n=26$, $52 \%$ ) was identified as the most frequently prescribed drug group in the FRID list. The five most commonly 
prescribed drugs in the FRID list are quetiapine $(n=6)$, fluvoxamine $(n=5)$, risperidone $(n=5)$, tramadol $(n=4)$, and haloperidol $(n=4)$. In contrast, the most commonly prescribed drug groups in the ODs list were discovered to be $\mathrm{C} 08(\mathrm{n}=97,34.3 \%)$ and $\mathrm{C} 09(\mathrm{n}=59,20.8 \%)$. The use of $\mathrm{C} 07$ (mean rank $=110.94$ ) was found to be significantly higher among residents with an elevated risk of falls $(p=0.029)$ than those who were not (mean rank $=98.39$ ). Similarly, respondents who presented an increased risk of falling (mean rank $=111.54$ ) were also predisposed to a significantly greater level of C09 use $(\mathrm{p}=0.036)$ than those who were not (mean rank $=$ 108.00)

Overall, two-fifths of the FRQ items (5 out of 12) were marked 'yes' by a majority of the residents. Residents most frequently approved the necessity to push with hands to rise from a chair $(n=158,74.5 \%)$, while the lowest percentage was found for the question suffering from sadness or depression $(n=6,2.8 \%)$. Approximately three-fifths of the residents had reported fear of falling when engaging in ADL $(n=133,62.7 \%)$. Unsteadiness in walking was endorsed by more than half of the residents $(\mathrm{n}=117,55.2 \%)$. Despite the high rate of unsteadiness in walking, a total of $150(70.8 \%)$ residents reported no falls in the previous six months. A majority of them even excluded the concern of medication causing lightheadedness or tiredness $(n=183,86.3 \%)$. Specifically, a large proportion of the residents $(n=199,93.9 \%)$ omitted the use of medications that improve sleep and mood.

Using the fall efficacy scale, the mean scores for all individual items in the full samples were fairly précised to a defined array of approximately 3 . Overall, the mean score of all participants ranged from $3.18 \pm 1.51$ to $3.86 \pm 1.61$. Likewise, nearly four-fifths of the individual items on FES displayed an identical range of scores with a reported range from 1-8 for questions 3 to 10 . Residents most frequently perceived fear in walking around the house $($ mean $=3.86, \mathrm{SD}=1.61$ ), followed by getting in and out of a chair (mean $=3.67, \mathrm{SD}=1.51$ ) and taking a bath or shower (mean $=3.53, \mathrm{SD}=1.48$ ). Conversely, the tasks that created the highest falls efficacy with the lowest score were observed to be personal grooming (mean $=3.18, \mathrm{SD}=1.51$ ) and preparing meals (mean $=3.38, \mathrm{SD}=1.59$ ).

Table 3 shows the results of the univariate and multivariate analyses conducted to determine the predictors of high-risk falls. The univariate analysis showed that the length of stay in facilities was a significant predictor of increased risk of falls $(p=0.040)$. In particular, those who have stayed at the facilities less than one year were associated with significantly greater odds of falling (OR 5.462, 95\% CI 1.27-23.46; $\mathrm{p}=0.022$ ). Similarly, frailty status was also significantly associated with a higher risk of falls $(\mathrm{p}<0.001)$. Frail residents were associated with significantly greater odds in falling (OR $36.4,95 \%$ CI 4.47-296.37; $\mathrm{p}=0.001$ ) relative to pre-frail residents. The total number of drugs (OR 1.13, 95\% CI $1.02-1.24 ; \mathrm{p}=0.024)$ and drugs as needed (OR 1.85, 95\%
CI 1.06-3.23) were associated with falls. Additionally, elderly people who took C07 (beta-blocking agents) and C09 (renin-angiotensin system inhibitors), respectively, were 2.61 fold $(95 \%$ CI 1.08-6.29; $\mathrm{p}=0.033)$ and 2.06 fold $(95 \%$ CI $1.04-4.08 ; \mathrm{p}=0.038)$ more likely to experience falls. All the variables mentioned earlier were entered into the multivariate logistic analysis. The multivariate analysis indicated that only frailty status (pre-frail and frail) remained significant as an independent risk factor in causing falls $(p<0.001)$. Identical to the findings from the univariate analysis, frail residents were associated with a higher risk of falling compared to pre-frail (OR 24.405, 95\% CI 2.84-209.73; $\mathrm{p}=0.004)$ in the multivariate analysis.

In this study, the pre-frail prevailed over the frail, representing a borderline between robust and frail. The high proportion of pre-frail residents could be due to the presence of multiple comorbidities and increased care needs associated with cognitive impairment among the elderly residents. When specific FRIDs or ODs were evaluated for causing falls, only beta-blocking agents (C07) and renin-angiotensin system inhibitors (C09) were found to be associated with a higher risk of falling. Although the association between antihypertensive agents and falls via orthostatic hypotension has long been implicated, the relationship with class-specific adverse effects remained unclear (Gribbin et al. 2011). No specific antihypertensive agent has been associated with an increased risk of falls as previous studies have shown mixed results involving participants at different phases of treatment such as initiation and continuation phases (Lipsitz et al. 2015). The use of antihypertensive agents at different stages of treatments may confer substantial disparities in the outcome of fall risks. Generally, a significantly higher risk of falling was proven during the initiation of antihypertensive agents in the first 14 days, with the results consistent to all classes of antihypertensive classes (Butt et al. 2013). In contrast, the prolonged and sustained use of antihypertensive agents may substantially reduce fluctuation in blood pressure that results in hypotension, thereby decreasing the attendant risk in falling. With regards to beta-blockers, the association between the use of beta-blocking agents and fall risk has been evaluated in other studies, but with no association found in most cases (Gribbin et al. 2011). Currently, prescribed beta-blockers have been shown to possess significant protective effects against falls in some studies. Beta-blockers have been proven to attenuate the raised levels of catecholamine, thus conferring protective effects on vasovagal syncope and falls (Frankenstein et al. 2007). Thus, it is suggested that analytical results should be further implemented to sort out the causal agents in causing fall incidences by taking into account the specific classes of beta-blocking agents as well as the duration of treatment.

The risk of falls also appeared to be significantly increased with the use of renin-angiotensin system inhibitors (C09). This is supported by a meta-analysis 
showing that ACE inhibitors were associated with a small but significant risk effect on bone fractures, particularly among older people (Cheng et al. 2017). However, conflicting findings have been shown in many studies, whereby no association was found with the precipitation of falls (Kuschel et al. 2015). Overall, in examining the association between falls and drug use, the factors of dosage increment or duration of treatments should be taken into account to identify the real culprit. This present study showed that residents who reside in nursing homes for less than one year were more likely to experience falls relative to more extended periods of stay. Unlike long-term care residents who have stayed in a residential care facility for extended periods of time, the underlying reason of elevated fall risk among short-stay residents within one year could be possibly due to the unfamiliar environment. To the best of authors' knowledge, this study presented the first comprehensive examination of possible contributing factors, particularly the use of FRIDs or ODs in association with fall risk status among elderly people residing in nursing homes. In this study, only frailty status was found to be independently associated with an increased risk of falling. A similar finding was observed in a descriptive study conducted under home care in which frail elderly people were found to be subjected to double or triple fold fall risk compared to those who are non-frail (Pi et al. 2015). Weak elderly have also been proven to be significantly associated with recurrent falls and fractures. Most studies have demonstrated that frail elderly people are subjected to the loss of muscle mass which is one of the significant components of frailty syndrome that predisposes higher fall risk (Tchalla et al. 2012).

The use of fall-risk increasing drugs are significant among elderly people residing in nursing homes and it is further being complicated with the lack of medication monitoring and the complexity of illnesses in this particular population. While some nursing homes in Malaysia employ nursing aides and skilled nurses, there were unclear roles and responsibility of who manages the medication in non-government-funded nursing homes (Nizaruddin et al. 2017). Therefore, a simple medication check-list on the common drugs that pose high risk to cause fall should be made available in all nursing homes in order to help care-takers or administrators monitor their residents ' health as well as to enable them to identify which residents require further medical assessment.

TABLE 1. Association of respondent's characteristics with fall risk status $(\mathrm{N}=212)$

\begin{tabular}{lllll}
\hline \multicolumn{1}{c}{ Variable/characteristics } & Frequency, $\mathrm{n}(\%)$ & Fall risk status \\
& & $\begin{array}{c}\text { High risk of falling } \\
(\mathrm{N}=137)\end{array}$ & $\begin{array}{c}\text { Low risk of falling } \\
(\mathrm{N}=75)\end{array}$ & P-value \\
\hline Age (years), n (\%) & $44(20.8)$ & $24(54.5)$ & $20(45.5)$ \\
$65-69$ & $49(23.1)$ & $30(61.2)$ & $19(38.8)$ \\
$70-74$ & $47(22.2)$ & $30(63.8)$ & $17(36.2)$ \\
$75-79$ & $37(17.5)$ & $26(70.3)$ & $11(29.7)$ \\
85 or above & $35(16.5)$ & $27(77.1)$ & $8(22.9)$
\end{tabular}

Gender, $\mathrm{n}(\%)$

Male

83 (39.2)

49 (59.0)

34 (41.0)

Female

$129(60.8)$

88 (68.2)

$41(31.8)$ 
Education level, n (\%)

No formal education

Primary school

Secondary school

University and above

Length of stay in facilities (years),

n $(\%)$

$<1$ year

$1-5$

6-10

11 or above

Frailty status, n (\%)

Robust

Pre-frail

Frail

Taking $\geq 1$ FRIDs or ODs, n (\%)

Yes

145 (68.4)

95 (65.5)

67 (31.6)

42 (62.7)

$71(73.2)$

76 (35.8)

47 (61.8)

$16(53.3)$

$3(33.3)$

$76(35.8)$

$20(26.3)$

$122(57.5)$

104 (85.2)

14 (6.6)

$13(92.9)$

26 (26.8)

29 (38.2)

14 (46.7)

$6(66.7)$

$0.031^{\mathrm{a}^{*}}$

56 (73.7)

$18(14.8)$

$<0.001^{\mathrm{a}^{*}}$

$1(7.1)$

No of drugs, mean rank

Total

114.42

92.04

$0.010^{\mathrm{b}^{*}}$

Continuous use

112.41

95.70

$0.055^{\mathrm{b}}$

As needed

111.22

97.87

$0.025^{b^{*}}$

No of FRIDs, mean rank

Total

105.55

108.23

$0.641^{\mathrm{b}}$

Continuous use

104.47

107.64

110.20

$0.276^{\mathrm{b}}$

As needed

No of ODs, mean rank

Total

108.65

102.57

$0.475^{b}$

Continuous use

108.26

103.29

$0.560^{\mathrm{b}}$

As needed

107.05

105.50

$0.294^{\mathrm{b}}$

$\mathrm{a}=$ Chi-square test

$\mathrm{b}=$ Mann-Whitney U test

*Significant at the 0.05 level (2-tailed) 
TABLE 2. Association of FRIDs and ODs with fall risk status

\begin{tabular}{|c|c|c|c|c|}
\hline \multirow{2}{*}{$\begin{array}{c}\text { FRIDs } \\
\text { ATC*code }\end{array}$} & \multirow[b]{2}{*}{$\begin{array}{c}\text { Frequency, } \mathrm{n} \\
(\%)\end{array}$} & \multicolumn{2}{|c|}{ Fall risk status } & \multirow[b]{2}{*}{ P-value } \\
\hline & & $\begin{array}{c}\text { High risk of } \\
\text { falling, mean rank }\end{array}$ & $\begin{array}{c}\text { Low risk of } \\
\text { falling, mean rank }\end{array}$ & \\
\hline N06A (Antidepressants) & $11(22.0)$ & 106.98 & 105.63 & $0.712^{\mathrm{a}}$ \\
\hline N05B (Anxiolytics) & $5(10.0)$ & 106.32 & 106.83 & $0.827^{\mathrm{a}}$ \\
\hline $\begin{array}{l}\text { N05C (Hypnotics and } \\
\text { sedatives) }\end{array}$ & $3(6.0)$ & 106.55 & 106.41 & $0.941^{\mathrm{a}}$ \\
\hline N02A (Opioids) & $5(10.0)$ & 107.87 & 104.00 & $0.095^{\mathrm{a}}$ \\
\hline N05A (Antipsychotics) & $26(52.0)$ & 105.08 & 109.09 & $0.399^{\mathrm{a}}$ \\
\hline Total & $50(100)$ & & & \\
\hline \multicolumn{2}{|l|}{ ODs } & \multicolumn{2}{|c|}{ Fall risk status } & \multirow[b]{2}{*}{ P-value } \\
\hline ATC*code & Frequency, n(\%) & $\begin{array}{c}\text { High risk of } \\
\text { falling, mean rank }\end{array}$ & $\begin{array}{c}\text { Low risk of } \\
\text { falling, mean rank }\end{array}$ & \\
\hline C03 (Diuretics) & $29(10.3)$ & 105.59 & 108.16 & 0.619 \\
\hline N06A (Antidepressants) & $11(3.9)$ & 106.98 & 105.63 & 0.712 \\
\hline $\begin{array}{l}\text { C01D (Vasodilators used in } \\
\text { cardiac diseases) }\end{array}$ & $4(1.4)$ & 106.55 & 106.41 & 0.936 \\
\hline C07 (Beta-blocking agents) & $36(12.7)$ & 110.94 & 98.39 & 0.029 \\
\hline $\begin{array}{l}\text { C09 (Renin-angiotensin } \\
\text { system inhibitors) }\end{array}$ & $59(20.8)$ & 111.54 & 97.27 & 0.036 \\
\hline $\begin{array}{l}\text { C08 (Calcium channel } \\
\text { blockers) }\end{array}$ & $97(34.3)$ & 105.68 & 108.00 & 0.761 \\
\hline N05A (Antipsychotics) & $26(9.2)$ & 105.08 & 109.09 & 0.399 \\
\hline $\begin{array}{l}\text { N04B (Dopaminergic } \\
\text { agents) }\end{array}$ & $6(2.1)$ & 107.59 & 104.50 & 0.136 \\
\hline $\begin{array}{l}\text { G04CA (Alpha- } \\
\text { adrenoreceptor antagonists) }\end{array}$ & $10(3.5)$ & 106.65 & 106.22 & 0.888 \\
\hline C02 (Antihypertensives) & $5(1.8)$ & 106.32 & 106.83 & 0.827 \\
\hline Total & $283(100)$ & & & \\
\hline
\end{tabular}

TABLE 3. Univariate and multivariate logistic analysis of predictors for high-risk falls

\begin{tabular}{lcccccc}
\hline \multirow{2}{*}{ Risk factor } & \multicolumn{3}{c}{ Univariate logistic analysis } & \multicolumn{3}{c}{ Multivariate logistic analysis } \\
& OR & $95 \%$ CI & P-value & OR & $95 \%$ CI & P-value \\
\hline $\begin{array}{l}\text { Length of stay in } \\
\text { facilities } \\
<1 \text { year }\end{array}$ & & & $0.040^{*}$ & & & 0.359 \\
$1-5$ & 5.462 & $1.272-23.445$ & $0.022^{*}$ & 3.012 & $0.441-20.591$ & 0.261 \\
$6-10$ & 3.241 & $0.752-13.973$ & 0.115 & 1.823 & $0.265-12.542$ & 0.542 \\
11 & 2.286 & $0.480-10.883$ & 0.299 & 1.400 & $0.183-10.728$ & 0.746
\end{tabular}


Frailty status

Robust

Pre-frail

Frail

No of drugs

Total

1.124

$1.016-1.244$

As needed

1.851

$1.062-3.226$

C07 (Beta-blocking agents)
$<0.001^{*}$

Reference

16.178

7.915-33.066

4.471-296.374

$<0.001 *$

14.676

$0.001 *$

24.405

2.840-209.734

Reference

7.000-30.768

$<0.001^{*}$

$0.004 *$
$<0.001^{*}$

\section{C09 (Renin-}

angiotensin system

2.061

$1.042-4.080$

$0.038^{*}$

1.997

$0.745-5.351$

0.169

\section{CONCLUSION}

The present study showed that the use of FRIDs and ODs are alarming among elderly people residing in nursing homes. A majority of elderly people residing in nursing homes took at least one FRID or OD. Frailty status was found to be the only independent factor significantly associated with heightened fall risks, with frail elderly people presenting a higher fall risk compared to those who are non-frail.

\section{ACKNOWLEDGEMENTS}

This work was supported by Universiti Kebangsaan Malaysia's research grant GUP-2017-010.

\section{REFERENCES}

Butt, D., Mamdani, M., Austin, P., Tu, K., Gomes, T. \& Glazier, R. 2013. The risk of falls on initiation of antihypertensive drugs in the elderly. Osteoporosis International 24(10): 2649-2657.

Cheng, Y.Z., Huang, Z.Z., Shen, Z.F., Wu, H.Y., Peng, J.X., Waye, M.M.Y., Rao, S.T. \& Yang, L. 2017. Ace inhibitors and the risk of fractures: A meta-analysis of observational studies. Endocrine 55(3): 732-740.

Cullinan, S., O'mahony, D., O'Sullivan, D. \& Byrne, S. 2016. Use of a frailty index to identify potentially inappropriate prescribing and adverse drug reaction risks in older patients. Age and Ageing 45(1): 115-120.

Frankenstein, L., Nelles, M., Slavutsky, M., Schellenberg, D., Boesch, A., Katus, H., Remppis, A. \& Zugck, C. 2007. Betablockers influence the short-term and long-term prognostic information of natriuretic peptides and catecholamines in chronic heart failure independent from specific agents. Journal of Heart and Lung Transplantation 26(10): 10331039.

Ghazi, H.F., Elnajeh, M., Abdalqader, M.A., Baobaid, M.F., Rosli, N.S.R. \& Syahiman, N. 2017. The prevalence of falls and its associated factors among elderly living in old folks home in Kuala Lumpur, Malaysia. International Journal of Community Medicine and Public Health 4(10): 3524-3529.

Gribbin, J., Hubbard, R., Gladman, J., Smith, C. \& Lewis, S. 2011 Risk of falls associated with antihypertensive medication: Self-controlled case series. Pharmacoepidemiology and Drug Safety 20(8): 879-884.

Kuschel, B.M., Laflamme, L. \& Möller, J. 2015. The risk of fall injury in relation to commonly prescribed medications among older people - a Swedish case-control study. European Journal of Public Health 25(3): 527-532.

Lipsitz, L.A., Habtemariam, D., Gagnon, M., Iloputaife, I., Sorond, F., Tchalla, A.E., Dantoine, T.F. \& Travison, T.G. 2015. Reexamining the effect of antihypertensive medications on falls in old age. Hypertension 66(1): 183-189.

Milos, V., Bondesson, Å., Magnusson, M., Jakobsson, U., Westerlund, T. \& Midlöv, P. 2014. Fall risk-increasing drugs and falls: A cross-sectional study among elderly patients in primary care. BMC Geriatrics 14(1): 40.

Morley, J.E., Malmstrom, T.K. \& Miller, D.K. 2012. A simple frailty questionnaire (FRAIL) predicts outcomes in middle aged African Americans. The Journal of Nutrition, Health \& Aging 16(7): 601-608.

Nizaruddin, M.A., Omar, M.S., Mhd-Ali, A. \& Makmor-Bakry, M. 2017. A qualitative study exploring issues related to medication management in residential aged care facilities. Patient Preference and Adherence 11: 1869-1877 
Pi, H.Y., Hu, M.M., Zhang, J., Peng, P.P. \& Nie, D. 2015. Circumstances of falls and fall-related injuries among frail elderly under home care in China. International Journal of Nursing Sciences 2(3): 237-242.

Rubenstein, L.Z., Vivrette, R., Harker, J.O., Stevens, J.A. \& Kramer, B.J. 2011. Validating an evidence-based, self-rated fall risk questionnaire (FRQ) for older adults. Journal of Safety Research 42(6): 493-499.

Ryan-Atwood, T.E., Hutchinson-Kern, M., Ilomäki, J., Dooley, M.J., Poole, S.G., Kirkpatrick, C.M., Manias, E., Mitra, B. $\&$ Bell, J.S. 2017. Medication use and fall-related hospital admissions from long-term care facilities: A hospital-based case-control study. Drugs \& Aging 34(8): 625-633.

Tchalla, A.E., Lachal, F., Cardinaud, N., Saulnier, I., Bhalla, D., Roquejoffre, A., Rialle, V., Preux, P.M. \& Dantoine, T. 2012. Efficacy of simple home-based technologies combined with a monitoring assistive center in decreasing falls in a frail elderly population (results of the Esoppe study). Archives of Gerontology and Geriatrics 55(3): 683-689.

van der Velde, N., Stricker, B.H.C., Pols, H.A. \& van der Cammen, T.J. 2007. Withdrawal of fall-risk-increasing drugs in older persons. Drugs \& Aging 24(8): 691-699.

Faculty of Pharmacy

National University of Malaysia

Jalan Raja Muda Abdul Aziz

53000 Kuala Lumpur, Federal Territory

Malaysia

*Corresponding author; email: marhanis@ukm.edu.my

Received: 18 March 2019

Accepted: 14 February 2020 